\title{
Colour Removal from Aqueous Solutions of the Reactive Azo Dye Remazol Black B Using the Immobilised Cells (Shewanella Strain J18 143) -Cellulose-g.co-Monomer System
}

\author{
T. LI ${ }^{1}$, J. T. GUTHRIE ${ }^{2}$ \\ ${ }^{1}$ College of Light Industry and Food Sciences, South China University of Technology, Guangzhou, China \\ ${ }^{2}$ Department of Colour Science, School of Chemistry, University of Leeds, Leeds, UK \\ E-mail:j.t.guthrie@leeds.ac.uk \\ Received October 12, 2009; revised November 9, 2009; accepted November 20, 2009
}

\begin{abstract}
Consideration is given here to colour removal, carried out using immobilised biological cells, Shewanella strain J18 143. In order to provide greater control of an overall colour removal process and to give a basis for the effective recovery of the cell culture species, cell immobilisation has been established on chemically modified cellulose. The modification was achieved by chemically inducing the graft copolymerisation of methacrylic acid onto cotton fabric. The immobilised cells were able to decolorise the dye. The immobilisation methods, physical adsorption, "growing-in" and chemical coupling, were compared. Each of the methods was effective to some extent. However, the latter two immobilisation methods provided the greater effect in decoloration. Each of these immobilised systems is relatively simple to achieve, whether by adsorption, physical interlocking or covalent coupling. The graft copolymer is able to offer versatility in use. The decoloration was shown to be rapid under relatively simple processing conditions. Thus, compared with the established controls, complete decoloration of solutions of Remazol Black B was observed. The potential use of the graft copolymer substrate as support for a biochemical agent was confirmed.
\end{abstract}

Keywords: Reactive Azo Dyes, Colour Removal, Immobilisation, Immobilised Cells

\section{Introduction}

Reactive dyes have great use in the textile industry, due to their good fastness properties, their provision of a wide range of bright colours and the significant flexibility in their application methods [1]. However, reactive dyes have been considered to be the basis of more environmental problematic compounds that arise from textile dye effluents [2]. Often, only $50-90 \%$ of the dye will react with the fabric, depending on the dye and on the application method [1,3]. As a result, the highly contaminated wastewater produced is a considerable pollution concern. Various colour removal methods for textile effluents have been extensively studied including physical, chemical, physico-chemical and biological treatments [4].

Approaches that involve physical and/or chemical processes to remove reactive azo dyes, and hydrolysed reactive azo dyes from the aqueous wastewaters can be costly to operate [5]. In this regard, the anaerobic reduction of azo dyes using a microbial sludge can provide an effective and economic treatment process for removing colour from reactive azo-dye wastewaters [6,7]. Colour removal from industrial wastewaters by biological cells is the subject of interest of many researchers. Several papers on the transformation of organic compounds by microorganisms have been published [8,9]. A factor to be considered is that the anaerobic degradation of reactive azo dyes involves not only a reduction of the azo bond but also the production of aromatic amines. The resultant aromatic amines resist further degradation and can be even more toxic than the dyes themselves $[10,11]$. Because of the toxic potential of the aromatic amines, further degradation of the dye compound is necessary if this toxicity potential is to be eliminated or reduced [12]. A high percentage of the intermediates of the azo dyes have been identified as carcinogens [10]. A proportion of these aromatic amines can be aerobically degraded [13]. In addition, the aromatic amines can be autoxidised to 
products that are expected to be easily removed, e.g. by attachment to flocculants that can then be easily separated [11]. A two stage mechanism for azo-reduction has been proposed, as shown below [14]:

$$
\begin{aligned}
& 2 e^{-}+2 H^{+}+\left(R-N=N-R^{\prime}\right) \rightarrow\left(R-N H-N H-R^{\prime}\right)(1) \\
& 2 e^{-}+2 H^{+}+\left(R-N H-N H-R^{\prime}\right) \rightarrow\left(R-N H_{2}\right)+\left(R^{\prime}-N H_{2}\right)(2)
\end{aligned}
$$

Here, it is speculated that the intermediate product of reaction (1) would be unstable and colourless. However, the azo bond can be reformed upon oxidation, regaining some of the colour. Hence, step (2) is required.

The bacterial degradation of textile dyes has been investigated by a large number of researchers. Some of these studies that have been reported in the literature have been summarised and discussed by Willmott [15] and by Pearce et al. [7]. Shewanella putrefaciens are nonfermentative facultative aerobes (obligate respirers), that are capable of the dissimilatory reduction of many different electron acceptors [16]. Shewanella strain J18 143 cells that were isolated from a textile wastewater have been shown to be capable of removing selected azobased colorants from wastewater [15].

Colour removal from textile wastewaters using immobilised cells can offer many advantages over the free cells in industrial and analytical applications [17,18]. The stability of immobilised cells can be improved, relative to the stability of the non-immobilised equivalents. Better control of reduction is achievable. The immobilised cells can be easily removed from the reaction system and, under appropriate conditions, can be used repeatedly and flexibly to make the continuous processes practical. Less equipment space is required for reaction using immobilised cells and a high cell concentration can be introduced in the system. Furthermore, the immobilisation support components can provide a protective environment for the cells against denaturants, proteolysis and can give reduced susceptibility to contamination, so that the cells are less affected by any fluctuations in the characteristics of their surroundings [19].

The immobilisation of the proteins, enzymes and cells onto graft copolymeric substrates, has been undertaken since substrates containing hydroxyl groups provide the basis for effectiveness [20-23]. The grafting of monomers or mixture of monomers can greatly increase the number of reactive groups that can be used for such immobilisation. The extent of incorporation of hydrophilic or hydrophobic groups can be controlled, creating a microenvironment that could improve the viability and stability of the biological materials that have been immobilised [18].

The present work relates to an investigation of the colour removal from reactive azo dye solutions brought about using biological cells that were covalently coupled to cotton cellulose graft copolymeric support systems. The cell system is that of Shewanella strain J18 143. In this study, a grafting reaction was carried out on cotton fabric, using potassium persulphate as the initiator and methacrylic acid as the monomer. Three immobilisation methods for the cells, physical adsorption, "growing-in" and chemical coupling, were used and compared. The Remazol Black B reactive azo dye was chosen as a model for this study of the effectiveness of immobilised cells in chromophore destination.

\section{Materials and Methods}

\subsection{Materials}

The reagents that were used in this study were of analytical grade, obtained from Sigma-Aldrich Gillingham (Dorset, UK), unless otherwise stated.

A cellulose-g.co-monomer system was chosen as the immobilisation substrate. The cellulose used was in the form of bleached cotton fabric, supplied by Whaleys Ltd. (Bradford, UK). The cotton fabric was washed with detergent and then thoroughly rinsed with deionised and distilled water before being dried at $60{ }^{\circ} \mathrm{C}$. The dried cotton fabric was kept in a desiccator before use. Potassium persulphate was chosen as the initiator. The monomer grafted onto the cotton cellulose fabric was methacrylic acid.

Shewanella strain J18 143 cells were grown in Tryptone Soy Broth (TSB, Lab M, Bury, Lancashire, UK) medium. To prepare a sterile culture medium, the TSB solution was made up with distilled water and was autoclaved for 15 minutes at $121^{\circ} \mathrm{C}$. All of the decoloration work was carried out in a Phosphate Buffer Saline (PBS) medium solution in $10 \mathrm{~cm}^{3}$ glass vials. The $\mathrm{pH}$ of the buffer solution was adjusted to $7 \pm 0.2$. Remazol Black B dye (Dystar UK Ltd., Huddersfield, UK) was used as the selected azo dye, in solution as a representative of the real textile effluents.

\subsection{Graft Copolymerisation Procedures}

The initial swelling of the cotton cellulose was achieved by stirring the cotton fabric slivers at $28{ }^{\circ} \mathrm{C}$ in distilled water for 2 hours, followed by soaking in the system overnight.

The swollen cotton fabrics were stirred gently for 60 minutes in an aqueous solution containing potassium persulphate $\left(0.075 \mathrm{~mol} \mathrm{dm}^{-3}\right)$ at $28{ }^{\circ} \mathrm{C}$. After one hour of impregnation of the pre-treated fabrics, purified methacrylic acid $\left(0.5 \mathrm{~mol} \mathrm{dm}^{-3}\right)$ was added into the reaction system, drop wise. The treatment was allowed to proceed at $50{ }^{\circ} \mathrm{C}$, in a water bath, for 5 hours. At the end of the desired reaction period, the fabrics were washed repeatedly and thoroughly with distilled water at $60{ }^{\circ} \mathrm{C}$ in the water bath for 60 minutes, to dissolve and then remove any produced, extractable homopolymer. Then the grafted fabric was re-washed with distilled water and 
dried at $35^{\circ} \mathrm{C}$ in the oven until a constant weight was achieved.

The graft yield was quantified as the percentage increase in weight of the samples after grafting, expressed as follows

$$
\% \text { GraftYield }=\left(\frac{W_{\text {GraftedCellulose }}-W_{\text {OriginalCellulose }}}{W_{\text {OriginalCellulose }}}\right) \times 100
$$

\subsection{Immobilisation of Shewanella Strain J18 143}

\subsubsection{Free Cell Preparation}

To initiate the cell growth process, a loop of inoculum of Shewanella strain J18 143 was put into $50 \mathrm{~cm}^{3}$ of the prepared growth medium, in $250 \mathrm{~cm}^{3}$ conical flasks. The flasks were sealed and were left overnight in a water shaker bath (Grant Instruments Ltd, Cambridge, UK) and incubated at $30{ }^{\circ} \mathrm{C}$, with shaking at $200 \mathrm{rpm}$. Then aerobic cultures of Shewanella strain J18 143 were grown in $100 \mathrm{~cm}^{3}$ universal bottles, containing $90 \mathrm{~cm}^{3}$ of the autoclaved culture medium, sealed with butyl rubber stoppers and inoculated with $9 \mathrm{~cm}^{3}$ of the aerobic culture. To obtain sufficient anaerobic cell growth, the bottles were incubated for 4 hours at $35^{\circ} \mathrm{C}$, without shaking.

The cells were harvested by centrifugation at 3300 rpm for 10 minutes, using a Jouan Centrifuge C3-12 (Jouan Ltd., UK) and washed twice in PBS solution. The cells supernatant in PBS was adjusted to a consistent absorbance value at $600 \mathrm{~nm}$, to ensure that the concentration of protein in each reduction experiment was the same (Specord S100 UV-visible spectrophotometer, Sarstedt Ltd., Leicester, UK). This prepared cell suspension was used immediately.

\subsubsection{Immobilisation of Shewanella Strain J18 143 onto the Substrate}

Three immobilisation methods were used in the study (Figure 1), a "growing-in" method, a physical adsorption method and a chemical coupling method. The immobilisation method of "growing-in" was aimed at growing the biological cells within the texture of the cotton cellulose copolymeric substrate for immobilisation.

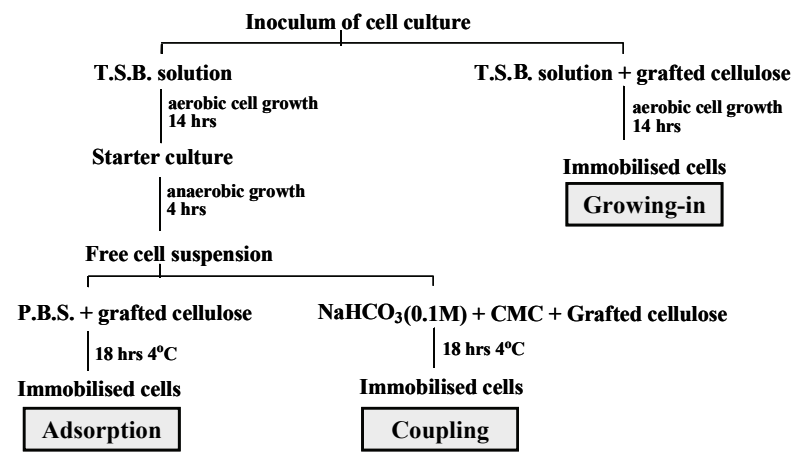

Figure 1. Biological cells immobilisation methods.
The method of adsorption was aimed at allowing the biological cells to be adsorbed onto the immobilisation substrate physically. The biological cells were also immobilised by chemical coupling [18]. The chemical coupling agent that was used to couple the cells onto the cotton cellulose copolymer substrate was CMC, 1-cyclohexy 1-3-[2-morphilinyl-4-ethyl] carbodi-imidome-thop-toluene sulphonate.

The immobilisation methods are summarised in Figure 1.

\subsection{Decoloration of Remazol Black B Dye Solutions Using Immobilised Cells of Shewanella Strain J18 143}

All of the reduction investigations were carried out in 10 $\mathrm{cm}^{3}$ vials. Each vial (Vial 2, Vial 3 and Vial 4) contained the dye solution $(50 \mu \mathrm{M})$, sodium formate $(21 \mathrm{mM})$, anthraquinone-2,6-disulphonic acid disodium salt (AQDS, $100 \mu \mathrm{M}$ ), the prepared immobilised cells and the required amounts of buffer solution to make up $9.5 \mathrm{~cm}^{3}$ in total volume, unless otherwise stated [22]. The vial notations (Vial 1 etc.,) are of relevance to the images presented in Figures 3 to 6.

To allow the reduction process to proceed under anaerobic conditions, all of the vials were degassed with nitrogen after initial sealing. The samples were incubated at $30{ }^{\circ} \mathrm{C}$, unless otherwise stated, without shaking, for 7 days. Optical density readings were taken daily at $\lambda_{\max }$ of the sampling dye solutions (597 nm) using a Specord S100 UV-visible spectrophotometer. As the optical density was measured, photographic representations were taken (Nikon COOLPIX2500).

\subsection{Establishment of Standards}

To achieve a better understanding of the colour removal effect provided by the immobilised biological cells on the targeted dye solutions, several standard controls were established.

An immobilised cells standard (Vial 5) was used to establish the effect, if any, of the immobilised cells and that of the existing of the cotton cellulose copolymer immobilisation substrate on colour removal. The absorbance of the prepared systems, without the addition of dye solution, was measured as one of the colour removal controls. The bacterial cells were immobilised by the three different methods. The aim of operating this control was to investigate the effect of the immobilised cells on the measurement of the adsorption of the analysed solution.

A dye solution standard, (Vial 4), for Remazol Black $\mathrm{B}$, without any addition of biological cells, was prepared as the second control.

The cell growth medium used was tryptone soy broth. A cell growth medium solution standard, (Vial 6), was 
established using the "treated" graft cellulosic copolymer, (the graft cellulosic copolymer underwent the procedure of immobilisation by the method of "growing-in" with the absence of bacterial cells) instead of the immobilised cells, as the third control.

A control of grafted cotton cellulose copolymer standard, (Vial 7), was prepared. This fourth control used the grafted cotton cellulose substrate in the decoloration system.

The effect of the planktonic Shewanella strain J18 143 cells on the colour removal of Remazol Black B dye solutions has been well investigated [24]. A free cell standard using the prepared cell suspension $\left(0.5 \mathrm{~cm}^{3}\right)$ instead of the immobilised cells was established to make the fifth control.

\subsection{Protein Analysis}

The grafted cotton cellulose was cut into pieces of $1 \mathrm{~cm} \times$ $2 \mathrm{~cm}$. These pieces then underwent the particular immobilisation procedures. The grafted cellulose pieces with their immobilised cells were used for protein assay purposes.

The protein assay was performed using 96-well microtitre plates and an Anthos 2001 plate reader, equipped with kinetic software (Jencons Scientific Ltd., Leighton Buzzard, UK). The samples were prepared in the 96-well microtitre plate, as indicated in Table 1. In Table 1, the notation A1 to A10 refers to containers of the standard protein solution (S1 to S5 in duplicate). This approach was used to produce the calibration curve for the standard protein solution. B1 to B6 contained the cellulosic substrates on which the cells were immobilised by the method of physical adsorption (GC Ad). C1 to C6 contained the cotton cellulose copolymer substrates on which the cells were immobilised by the method of chemical coupling (GC CC). D1 to D6 contained the cellulosic substrates with immobilised cells that the cells were immobilised by the method of "growing-in" (GC GI). The immobilised cells (B1 to D6) were immersed in $50 \mu$ $\mathrm{dm}^{-3}$ of PBS solution $(10 \mathrm{mM}, \mathrm{pH} 7) .1 .0 \mathrm{~cm}^{-3}$ of the mixture (bicinchoninic acid-copper sulphate solution) was added to each of the well. The 96-well plate was then left in an incubator, at $30^{\circ} \mathrm{C}$ for 30 minutes. The values of the optical density of the standard protein solu-

Table 1. Preparation of protein assay samples in 96-well plate.

\begin{tabular}{lllllllllll}
\hline & 1 & 2 & 3 & 4 & 5 & 6 & 7 & 8 & 9 & 10 \\
\hline A & S1 & S1 & S2 & S2 & S3 & S3 & S4 & S4 & S5 & S5 \\
& GC & GC & GC & GC & GC & GC & $/$ & $/$ & $/$ & $/$ \\
B & Ad & Ad & Ad & Ad & Ad & Ad & & & & \\
& GC & GC & GC & GC & GC & GC & $/$ & $/$ & $/$ & $/$ \\
C & CC & CC & CC & CC & CC & CC & & & & \\
& GC & GC & GC & GC & GC & GC & $/$ &, &, & D \\
& GI & GI & GI & GI & GI & GI & & & & \\
\hline
\end{tabular}

tion and of the substrates with immobilised cells, after 30 minutes of incubation at $30^{\circ} \mathrm{C}$, were obtained by the plate reader (at $570 \mathrm{~nm}$ ).

The standard solutions identified in Table 1, containing Bovine Serum Albumin (BSA) and PBS, were prepared in disposable cuvettes. $1 \mathrm{~cm}^{3}$ of bicinchoninic acid-copper sulphate solution (50:1) was added. The cuvettes were left to stand at room temperature for $30 \mathrm{~min}$ utes. After this time, the absorbance at $562 \mathrm{~nm}$, of each of the solutions, with PBS as the reference, was measured. A calibration curve of absorbance versus protein concentration was produced from the absorbance of these standard solutions containing known concentrations of BSA.

\section{Results and Discussion}

The emphasis of the current paper lies in the use of graft copolymers as supports for immobilised cells that can be then be to used decolorise colored, waterborne effluents.

Three general issues are raised. These concern the nature of the prepared graft copolymer system, the use of these copolymers in the immobilisation of whole cells and the application of these cells in colorant destruction. The chosen grafting route is one that produces grafts, of varying chain length, randomly on the substrate backbone, [25]. Where controlled grafting is required, alternative methods must be used as described by Carlmark and Malmstrom [26], by Roy et al., [27] and by Sahnoun et al. [28].

For the current study, the random grafting approach was chosen so that a variety of access options could be available for the coupling and the binding of the cells of the Shewanella strain J18 143. Thus, the immobilised cells option, involving the use of a suitable graft copolymeric substrate, based on cotton, was chosen to give flexibility in action and in processing. Other possibilities were considered. These include the approach taken by Mahmoodi et al. [29], dealing with decoloration by UV-radiation induced oxidation, in the presence of a redox catalyst system, that taken by Long et al. [30], concerned with general approaches to the anaerobic and the aerobic treatment of organic compounds and that of $\mathrm{Xu}$ et al. [31], who decolorised dyes using Shewanella decolorationis S12.

The results considered below can be judged alongside those presented in these earlier reports. In general, the procedures used as described in this report offer the significant advantages in effectiveness that are described below.

\subsection{Colour Reduction of Remazol Black B Solutions Using the Shewanella Strain J18 143}

To evaluate the dye reduction rate, calibration curves 
(absorbance values at $\lambda_{\max }$ against known dye concentrations) for Remazol Black B solutions were established, as shown in Figure 2.

Analysis of the decoloration process, using visible spectrophotometry, supported by photographic evidence, was used to monitor the colour changes taking place during the reduction treatment.

The samples used during the investigation of the decoloration of Remazol Black B and the relative established standards were photographed, Figure 3.

In the system identified as "Vial 1" contained the standard dye solution together with the immobilised cells. These cells were immobilised through the "growing-in" method within the matrix of the cotton cellulose graft copolymer in the growth medium, i.e. if the cells had become attached, they would have been fixed/immobilised by the method of adsorption/entrapment. The system identified as "Vial 2" contained the dye solution and the graft copolymer support, linked via chemical coupling of the immobilised bacterial cells. The system, "Vial 3" contained the dye solution and the grafted cotton cellulose with the physically adsorbed cells. The system "Vial 4" represented the control of the standard dye solution. The system "Vial 5" was made up as the standard of the immobilised cells (see Experimental).

It can be seen from the images (Figure 3) that the standard of the immobilised cells (Vial 5) was yellow. The yellow coloration in the solution was due to the presence of cytochromes in the solution. The cytochromes are more likely released by a certain amount of cell lysis that occurred during the treatment [24] that was used in preparing the compositions. Moreover, the yellow colour of the samples disappeared when these samples were exposed to air, i.e. the solutions were "colourless" in the presence of air.

Figure 3 shows that all of the samples that were treated with immobilised cells were decolorised to some degree. Comparing the decoloration results of "Vial 1", "Vial 2" and "Vial 3" visually, the cells immobilised onto the grafted cotton cellulose by the method of "growing-in" provided a fast and efficient method of colour removal. The colour of the sample that was placed with the cells that were immobilised on to the grafted cotton cellulose by adsorption (Vial 3) was not completely removed. The process of decoloration by the cells that were immobilised by chemical coupling (Vial 2) was slower than that obtained with the cells that were located by "growing-in" adsorption/entrapment (Vial 1). One issue that needs to be recognised is that, although these three immobilisation processes were undertaken with the same concentration of the cell suspension and the same amounts of grafted cellulose were used, the biomasses of the immobilised cells would be unlikely to have been identical, despite the precautions that were taken. This could explain the differences described above. It should be noted that, despite these differences, effective colour

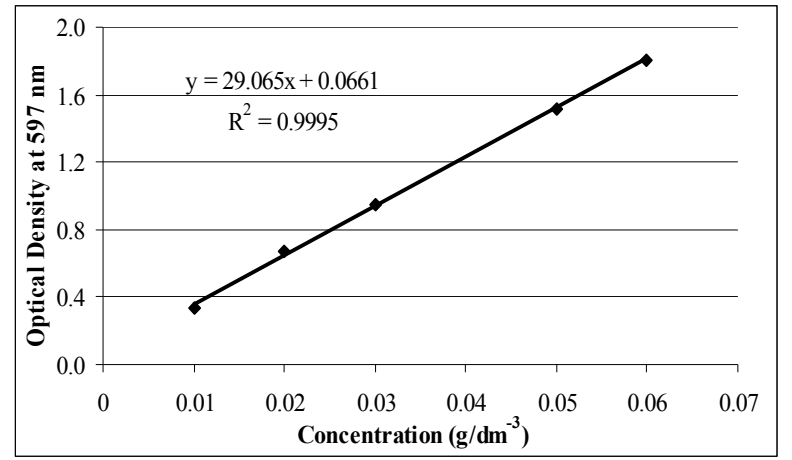

Figure 2. Calibration curve of solutions of the dye Remazol Black B

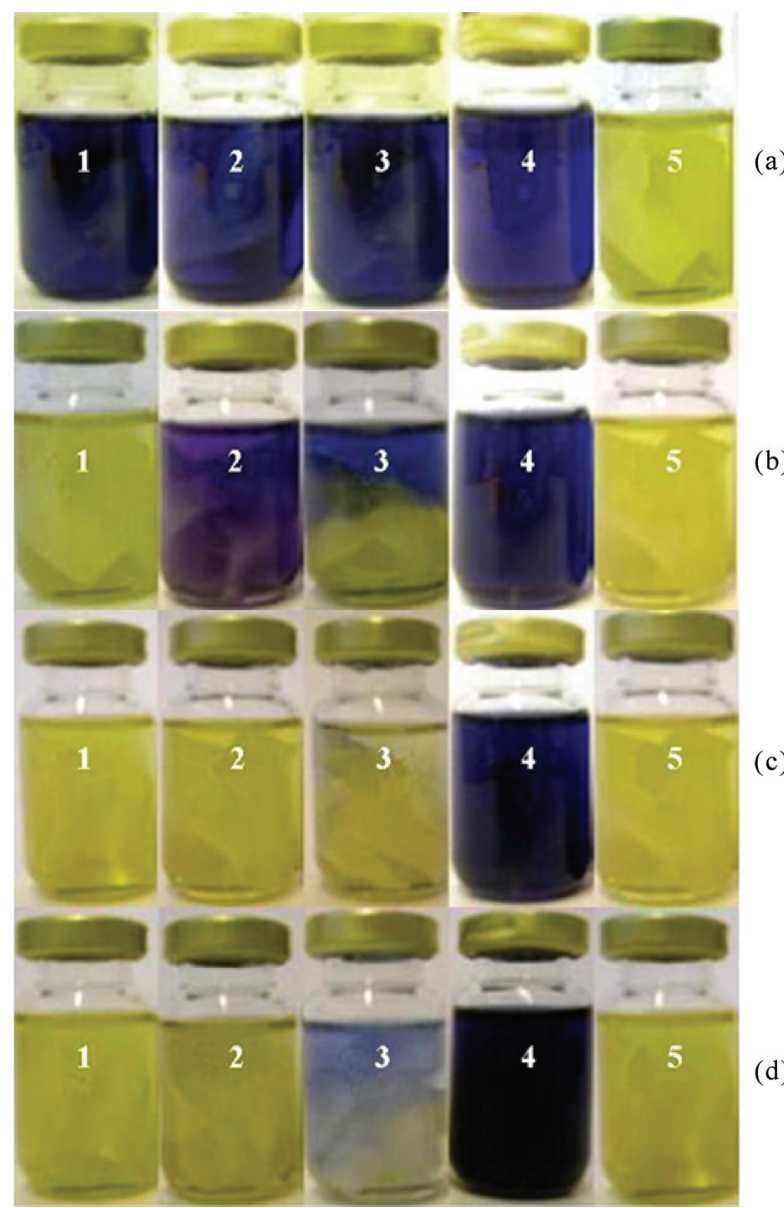

Figure 3. Results from the decoloration of solutions of Remazol Black B. The images represent the evaluated decoloration systems of "Vial 1", "Vial 2" and "Vial 3", and the standards of "Vial 4" and "Vial 5", taken over different periods of treating time: (a) 20 minutes; (b) 24 hours; (c) 96 hours; (d) 168 hours, respectively.

removal was observed.

\subsubsection{Control of the Cell Growth Medium Solution}

The immobilisation of bacterial cells by the "growing-in" method was carried out by immersing the grafted cellu- 


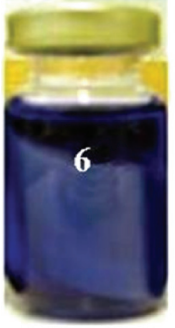

(a) $5 \mathrm{mins}$

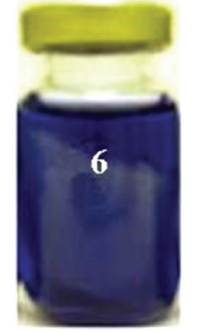

(b) $24 \mathrm{hrs}$

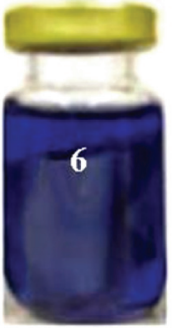

(c) $96 \mathrm{hrs}$

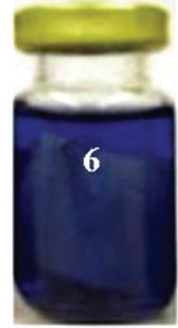

(d) $168 \mathrm{hrs}$
Figure 4. Established standard of the cellulose copolymeric substrate-contains solutions of Tryptone Soy Broth (the images of the standards that were taken in periods of time: a. 5 minutes; b. 24 hours; c. 96 hours; d. 168 hours after assembly).

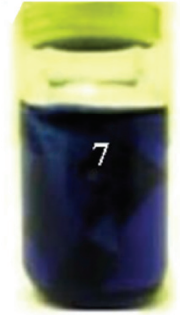

(a) 5 mins (b) $24 \mathrm{hrs}$

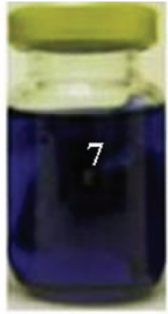

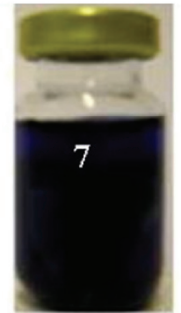

(c) $96 \mathrm{hrs}$

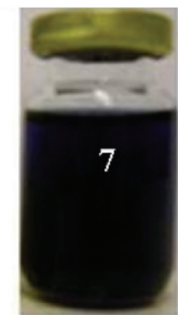

(d) $168 \mathrm{hrs}$
Figure 5. Established standard of the cellulose copolymeric substrate (the images of the standards were taken over periods of time: a. 5 minutes; b. 24 hours; c. 96 hours; d. 168 hours respectively).

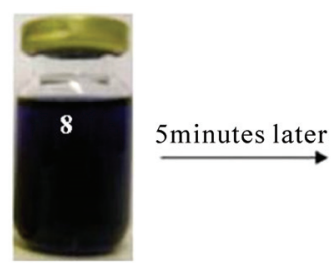

(a)

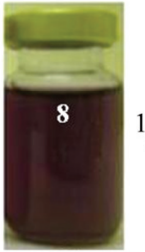

(b)

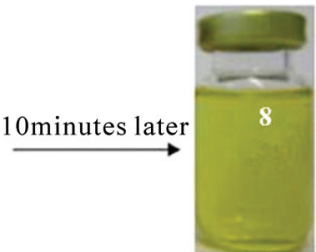

(c)
Figure 6. Decoloration flow profile for the decoloration with free Shewanella cells (the images of the standards were taken after periods of incubation: a. 10 seconds after injection of bacterial cells; b. 5 minutes later; c. 10 minutes later).

lose samples, together with the cell culture, into a cell growth medium. There could have been a small amount of residual TSB solution in the sample, after washing. Thus, the influence, if any, of the TSB on the decoloration of the dye solutions of Remazol Black B needed to be considered (Figure 4). "Vial 6" related to the standard control of TSB solution in which the composition corresponds to the parallel control, "Vial 1".

Figure 4 shows that the TSB solution has no effect on colour removal from the solutions of Remazol Black B. Since the TSB solution is a very rich medium that can be used for growing a wide range of bacteria, strict aseptic environments for the experiments were always used, with careful handling during the processes.

\subsubsection{Standard of Graft Cellulosic Copolymer}

A point needs to be considered as to whether or not the cotton cellulose-g.co-methacrylic acid immobilisation substrate had an effect on the decoloration of the Remazol Black B dye solution. This point was investigated by establishing the grafted cotton cellulose copolymer standard, "Vial 7".

Figure 5 shows that the immobilisation substrate, cotton cellulose-g.co-methacylic acid, had no influence on colour removal from the solution of Remazol Black B.

\subsubsection{Free Cells Standard}

Shewanella strain J18 143 has the ability to remove colour by degrading the chromophore of the reactive azo dyes $[15,19,24]$. In qualifying the use of immobilised biological cells, in the decoloration of reactive dye solutions, free cells standards were established, (Figure 6). It should be noted from "Vial 8", that the reduction of the black dye solution was rapidly achieved by the free biological cells. Actually, the colour removal process began before the nitrogen degassing was complete, as indicated in Figure 6.

The decoloration of the dye solution with free cells was much faster than that which was achieved with any of the grafted cellulose immobilised cells systems. However, the colour of the Remazol Black B dye solution was removed completely by the immobilised biological cells of Shewanella strain J18 143, within 24 hours of incubation. This result showed that there is a potential in using chemically modified cotton cellulose as an immobilisation substrate in decoloration systems, with the option of recycling and reuse.

\subsection{The Decoloration of Remazol Black B Solutions Using Immobilised Cells}

UV-visible spectophotometry was used as the main analysis support to evaluate the nature and the extent of the decoloration of the dye solutions. Figure 7 shows the absorbance versus time behaviour for the respective systems.

Figure 7 shows that the colour of the dye solution is removed completely within 24 hours by the system based on the "growing-in" of the immobilised cells (Vial 1). The removal of the colour was also completed by the system based on the chemical coupling of the immobilised cells (Vial 2). However, the decoloration that occurred was slower than that of the "growing-in" immobilised cells. The complete decoloration took about 48 hours of incubation. There was almost no change in colour within the first few hours in the system based on physically adsorbed cells (Vial 3). The colour was reduced at a much slower rate. Complete decoloration was not achieved. Compared with the standard of the dye 


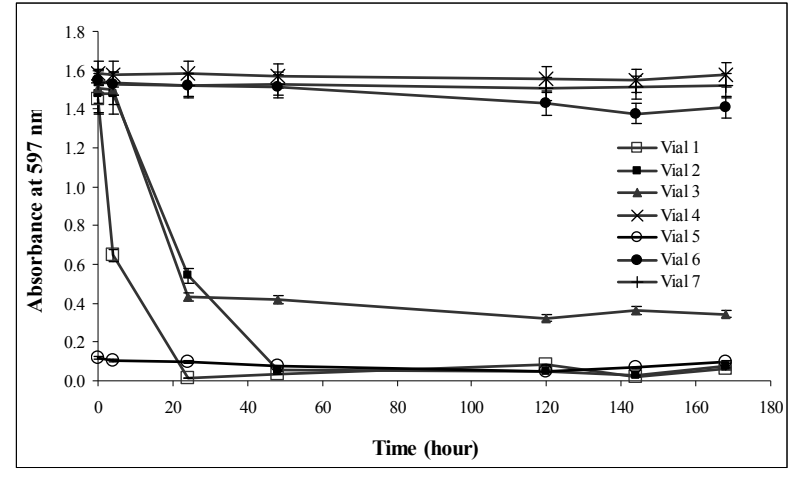

Figure 7. Results from the decoloration of Remazol Black $B$ dye solutions using the immobilised biological cells.

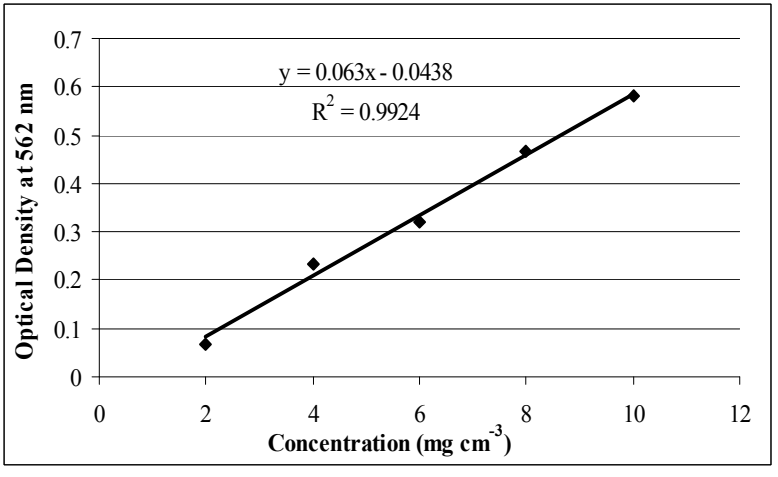

Figure 8. Calibration plot of standard protein solution assay.

Table 2. Results from protein analysis of immobilised bacterial cells.

\begin{tabular}{|c|c|c|c|c|c|c|c|c|c|c|}
\hline & 1 & 2 & 3 & 4 & 5 & 6 & 7 & 8 & 9 & 10 \\
\hline A & $\begin{array}{c}\mathrm{S} 1 \\
0.056\end{array}$ & $\begin{array}{c}\text { S1 } \\
0.081\end{array}$ & $\begin{array}{c}\text { S2 } \\
0.237\end{array}$ & $\begin{array}{c}\mathrm{S} 2 \\
0.233\end{array}$ & $\begin{array}{c}\text { S3 } \\
0.319\end{array}$ & $\begin{array}{c}\text { S3 } \\
0.319\end{array}$ & $\begin{array}{c}\text { S4 } \\
0.414\end{array}$ & $\begin{array}{c}\text { S4 } \\
0.467\end{array}$ & $\begin{array}{c}\text { S5 } \\
0.587\end{array}$ & $\begin{array}{c}\text { S5 } \\
0.582\end{array}$ \\
\hline B & $\begin{array}{c}\text { GC-Ad } \\
0.099 \\
2.275\end{array}$ & $\begin{array}{c}\text { GC-Ad } \\
0.184 \\
3.648\end{array}$ & $\begin{array}{c}\text { GC-Ad } \\
0.158 \\
3.228\end{array}$ & $\begin{array}{c}\text { GC-Ad } \\
0.159 \\
3.244\end{array}$ & $\begin{array}{c}\text { GC-Ad } \\
0.139 \\
2.291\end{array}$ & $\begin{array}{c}\text { GC-Ad } \\
0.149 \\
3.083\end{array}$ & I & I & I & I \\
\hline $\mathrm{C}$ & $\begin{array}{c}\text { GC-CC } \\
0.273 \\
5.087\end{array}$ & $\begin{array}{c}\text { GC-CC } \\
0.215 \\
4.149\end{array}$ & $\begin{array}{c}\text { GC-CC } \\
0.238 \\
4.521\end{array}$ & $\begin{array}{c}\text { GC-CC } \\
0.251 \\
4.731\end{array}$ & $\begin{array}{c}\text { GC-CC } \\
0.218 \\
4.198\end{array}$ & $\begin{array}{c}\text { GC-CC } \\
0.218 \\
4.198\end{array}$ & I & I & 1 & I \\
\hline D & $\begin{array}{c}\text { GC-GI } \\
0.468 \\
8.238\end{array}$ & $\begin{array}{c}\text { GC-GI } \\
0.488 \\
8.562\end{array}$ & $\begin{array}{c}\text { GC-GI } \\
0.504 \\
8.820\end{array}$ & $\begin{array}{c}\text { GC-GI } \\
0.530 \\
9.240\end{array}$ & $\begin{array}{c}\text { GC-GI } \\
0.408 \\
7.269\end{array}$ & $\begin{array}{c}\text { GC-GI } \\
0.430 \\
7.624\end{array}$ & I & I & 1 & I \\
\hline
\end{tabular}

solution (Vial 4), the cellulosic graft copolymer (Vial 7) and the growth medium of the bacteria (Vial 6) had no influence on the decoloration of the Remazol Black B dye solution.

\subsection{Comparison of Decoloration Effect of the Immobilised Cells between the Three Immobilisation Methods}

The results of this study have shown that using cotton cellulose-g.co-methacrylic acid as a support for biological cells immobilisation is practicable and effective in the current context. Comparisons of the decoloration efficiency between "Vial 1", "Vial 2" and "Vial 3" were carried out via the method of protein assay. The protein assay was designed on the basis of methods that are used for the protein determination of free biological cells $[22,32]$. The calibration curve of the standard protein solution is shown in Figure 8. The corresponding protein assay results, by the means of measured optical density values, of Table 1 are listed in Table 2. For the data presented in Table 2, the dye decoloration rate was calculated from the measuring results in the first 24 hours of incubation, based on the results from the protein assay of immobilised cells. The bacteria concentration used under each immobilisation method was an averaged value. It can be seen from Table 2 that the cells immobilised by the method of "growing-in" provided the most effective decoloration, as evaluated from both the dye reduction rate in the protein assay and the dye reduction measured by volumetric means. The cells immobilised by the method of adsorption, in the first 24 hours of incubation, show a greater reduction rate than that of the coupling immobilised cells. However, after 48 hours of incubation, the Remazol Black B was almost completely removed from the system by the cells that were immobilised by coupling but not by the cells that were immobilised by adsorption. One can conclude that all of the three different methods involving immobilised cells gave colour removal of the Remazol Black B from the investigated dye solution systems.

\section{Conclusions}

The described decoloration systems were successful with respect to the objective of colour removal from solutions of a reactive azo dye (Remazol Black B) using immobilised cells. The cotton cellulose fibre-g.co-methacrylic acid copolymer system can be used as immobilisation substrate for the biological cells of Shewanella strain J18 
143. In this case, "growing-in" and chemical coupling were better options for the immobilisation methods.

The cellulose-MAA copolymer shows potential in use as immobilisation substrate for the bacterial cells of Shewanella strain J18 143. Optimisation of the immobilisation system needs to be considered.

\section{References}

[1] K. N. Tapley, "Dyes and pigment properties and applications," Polymer Science Lecture, Department of Colour and Polymer Chemistry, UK: University of Leeds, 2002.

[2] J. García-Montaño, N. Ruiz, I. Muñoz, X. Domènech, J. A. Gracía-Hortal, F. Torrades, and J. Peral, "Environmental assessment of different photo-fenton approaches for commercial reactive dye removal," Journal of Hazardous Materials, Vol. 138, pp. 218-225, November 2006.

[3] A. J. Smith, "Colour removal from dyehouse effluents," Ph.D. thesis, University of Sheffield, UK, 2001.

[4] Y. M. Slokar and A. M. Le Marechal, "Methods of decoloration of textile wastewaters," Dyes and Pigments, Vol. 37, No. 4, pp. 335-356, May 1998.

[5] C. I. Pearce, R. Christie, C. Boothman, H. Canstein, J. T. Guthrie, and J. R. Lloyd, "Reactive azo dye reduction by Shewanella strain J18 143," Biotechnology and Bioengineering, Vol. 95, pp. 692-703, June 2006.

[6] T. H. Wallace, "Biological treatment of a synthetic dye water and an industrial textile wastewater containing azo dye compounds," Masters Dissertation, Virginia Polytechnic Institute and State University, USA, 2001.

[7] C. I. Pearce, J. R. Lloyd, and J. T. Guthrie, "The removal of colour from textile wastewater using whole bacterial cells: a review," Dyes and Pigments, Vol. 58, pp. 179196, September 2003.

[8] M. I. Banat, P. Nigham, D. Singh, and R. Marchant, "Microbial decolorization of textile dyes containing effluents: A review," Bioresource Technology, Vol. 58, pp. 217227, December 1996.

[9] A. Stolz, "Basic and applied aspects in the microbial degradation of azo dyes," Applied Microbiology and Biotechnology, Vol. 56, No. 1-2, pp. 69-80, July 2001.

[10] M. A. Brown and S. C. De Vito, "Predicting azo dye toxicity," Ccritical Reviews in Environmental Science and Technology, Vol. 23, No. 3, pp. 249-324, 1993.

[11] C. T. M. J. Frijters, R. H. Vos, G. Scheffer, and R. Mulder, "Decolorizing and detoxifying textile wastewater, containing both solution and insoluble dyes, in a full scale combined anaerobic/aerobic system," Water Research, Vol. 40, No. 6, pp. 1249-1257, March 2006.

[12] A. Gottlieb, C. Shaw, A. Smith, A. Wheatley, and S. Forsythe, "The toxicity of textile reactive azo dyes after hydrolysis and decolorisation," Journal of Biotechnology, Vol. 101, No. 1, pp. 49-56, February 2003.

[13] E. Razo-Flores, M. Luijten, B. A. Donlon, G. Lettinga, and J. A. Field, "Complete biodegradation of the azo dye azodisalycilate under anaerobic conditions," Environmental Science and Technology, Vol. 31, No. 7, pp. 2098-2103, 1997.

[14] D. T. Sponza and M. Işik, "Decolorization and azo dye degradation by anaerobic/aerobic sequential process," Enzyme and Microbial Technology, Vol. 31, No. 1-2, pp. 102-110, July 2002.

[15] N. J. Willmott, "The use of bacteria-polymer composites for the removal of colour from reactive dye effluents," Ph.D. thesis, University of Leeds, UK, 1997.

[16] D. A. Saffarini, T. J. DiChristina, D. Bermudes, and K. H. Nealson, "Anaerobic respiration of Shewanella putrefaciens requires both chromosomal and plasmid-borne genes," FEMS Microbiology Letters, Vol. 119, No. 3, pp. 271-278, January 1994.

[17] I. Chibata and T. Tosa, "Immobilized cells: Historical background," Applied Biochemistry Bioengineering, Vol. 4, pp. 1-9, 1983.

[18] M. H. M. Gil, "Immobilisation of proteins, enzymes and cells onto graft copolymeric substrates," Ph.D. thesis, University of Leeds, UK, 1983.

[19] A. Kamilaki, "The removal of reactive dyes from textile effluents - a bioreactor approach employing whole bacterial cells," Ph.D. thesis, University of Leeds, UK, 2000.

[20] D. Roy, S. Perrier, and J. T. Guthrie, "RAFT graft copolymerisation of 2-(dimethylanimoethyl) methacrylate onto cellulose fibres," Australian Journal of Chemsitry, Vol. 59, pp. 737-741, 2006.

[21] D. Roy, S. Perrier, and J. T. Guthrie, "Synthesis of natural-synthetic hybrid materials from cellulose via the RAFT process," Soft Matter, Vol. 4, pp. 145-154, 2008.

[22] T. Li, "Removal of colour from solutions of azo dyes using bacterial cells (Shewanella Strain J18 143)," Ph.D. thesis, University of Leeds, UK, 2007.

[23] D. Roy, J. Knapp, S. Perrier, and J. T. Guthrie, "Antimicrobial cellulose fibres via RAFT surface graft polymerisation," Biomacromolecules, Vol. 9, pp. 91-99, 2008.

[24] C. I. Pearce, "The reduction of coloured compounds using whole bacterial cells (Shewanella strain J18 143)," Ph.D. thesis, University of Leeds, UK, 2004.

[25] A. Hebeish and J. T. Guthrie, "The Chemistry and technology of cellulosic copolymers," Springer-Verlag, Heidelberg, ISBN 3-540-10164-0, 1981.

[26] A. Carlmark and E Malmstrom, Journal of the American Chemical Society, Vol. 124, pp. 900-901, 2002.

[27] D. Roy, J. T. Guthrie, and S.Perrier, Australian Journal of Chemistry, Vol. 59, pp. 737-741, 2006.

[28] M. Sahnoun, M. T. Charrayre, L. Vernon, T. Delait, and F. D'Agosto, Journal of Polymer Science, Part A-Polymer Chemistry, Vol. 43, pp. 3551-3565, 2005.

[29] N. M. Mahmoodi, M. Arami, N. Y. Limaee, and N.S.Tabrizi, Chemical Engineering Journal, Vol. 112, pp. 191-196, 2005.

[30] J. L. Long, H. D. Stensel, J. F. Ferguson, S. E. Strand, and J. E. Ongerth, Journal of Environmental Engineering, Vol. 119, pp. 300-320, 1993.

[31] M. Xu, J. Guo, G. Zeng, and X. Zhong, Applied Microbiology and Biotechnology, Vol. 71, pp. 246-251, 2006.

[32] P. K. Smith, R. I. Krohn, G. T. Hermanson, A. K. Mallia, F. H. Gartner, M. D. Provenzano, E. K. Fujimoto, N. M. Goeke, B. J. Olson, and D. C. Klenk, "Measurement of protein using binchiconinic acid," Analytical Biochemistry, Vol. 150, pp. 76-85, 1985. 